VOI. III. APRIL, $1893 . \quad$ NO. 3.

\title{
THE MONIST.
}

\section{RELIGION AND MODERN SCIENCE.}

\section{I.}

THE ancient conflict between religion and science is now, at the close of the nineteenth century, more animated than ever before. This conflict has formed the intellectual pivot of civilisation ever since Christianity first afforded the western peoples of Europe the inconsistent spectacle of a religion which made abundant use in its dogmatic constructions of the theories of contemporary science, and yet assumed a hostile attitude towards the fundamental principle of all science, the spirit of research and unbiassed judgment generally. Rightly has one of the acutest modern critics of Christianity, Ludwig Feuerbach, ${ }^{*}$ maintained, that the Christian sophistic philosophy is the necessary outcome of this inconsistency, which proclaims as absolute truth a definite, historical revelation, such as is found in the Bible, and simply assigns to the reason the subordinate and improper office of harmonising and defending what is there laid down.

There are, it is true, a great number of people, who are not disposed to see the bitterness of the conflict now raging. It has become customary for us to look upon the nineteenth century as an age of the comprehension of religion, and to distinguish it from the eighteenth century, which is regarded as a period of mere religious criticism. We boast of having rediscovered religion, and of having

*Wesen des Christenthums. First edition. I841. Pp. 288-289. 
secured to it a permanent province in the dominion of the mind. But the facts of our public life stand in curious contradiction to these assertions. In all civilised nations, in literature, in parliamentary procedures, in all questions that relate to religious and moral life or to education, the attentive observer will find that a profound chasm divides humanity. Every one feels the desirableness of bridging over this chasm, that the members of society may be united in common labor; but again and again we are made to experience how irreconcilable the respective claims of the opposed parties are. $\mathrm{He}$ who has studied the bulls and encyclical letters of the last two popes, Pius IX. and Leo XIII., and the commentaries on these utterances in the Civilta Cattolica, the official organ of the curia ; he who is acquainted with the polemical diatribes of the French Catholics against the positivists and freethinkers, and against the school and church legislation of the third republic; he who has any knowledge of that mass of controversial literature, which the proclamation of the doctrine of papal infallibility in the year 1870 evoked; he who has followed the eventful and varied history of the so-called "Culturkampf" in the German Empire, from the era of the minister Falk, down to the recent bill for a new School-law in Prussia, defeated amidst the greatest excitement in all parts of Germany; he who is the least bit at home in the literary feuds which are being fought out in the domain of historical theology concerning the validity and credibility of the original sources of Christianity; he, finally, who will place the writings of Cardinal Newman or of the Jesuits Pesch and Cathrein by the side of those of Huxley and Spencer, by the side of those of Du Bois-Reymond, Strauss, and Dühring : he, I say, who has gone through with a critical spirit all that I have cited in the preceding sentences, will surely not be apt to contradict this assertion of mine that civilised humanity to-day is separated into two groups which no longer understand each other, which do not speak the same language, and which live in totally different worlds of thought and sentiment-at least so far as this one critical point is concerned of man's relation to religion.

"Wie Ja und Nein sind sie, Wie Stur'm und Regentlogen." 
Have we, then, learned nothing and forgotten nothing since the days of rationalism? The tremendous labors which our own century' has devoted to the investigation of religion in all its forms, to the unfolding of its connection with racial mind and sentiment, and of its relation to civilisation generally, and finally to the elucidation of the origin and development of the great forms of religion: has all this had no other result than that we, after a century of the most laborious research, again find ourselves in the same attitude of unintelligent hostility towards religion and Christianity in which the eighteenth century revelled, and out of which we have only fought our way by the united efforts of a host of profoundly enlightened minds?

This argument has been advanced in opposition to the leaders of the rationalistic movement and to the work of the eighteenth century in varying forms, by the party which seeks to ally the science of the present and the religion of the past. It is seriously said and enjoined that only they who are far behind the science of the times and hold aloof from the true spirit of the age can still assume the repugnant attitude toward religion which was characteristic of the mind of the eighteenth century.

It is high time to point out the crude confusion of ideas which lies at the basis of this argument. It confounds the historical understanding of a thing with the philosophical approval of it. But these are two totally distinct things. We understand a phenomenon historically, when we are clear in our minds concerning the external conditions and habits of thought of humanity from which it sprung; when its main-springs of action and its purposes, as well as the effects which have proceeded from it, are distinctly traceable. The more closely our mental pictures of these things correspond to the facts as they actually were at the origin, and the more they conduct us from the mere surface of phenomena into the secrets of their psychological and sociological connection, and teach us to understand these things as products of mind and of society, the higher will our historical knowledge of them be rated. In this sense the knowledge which the eighteenth century had of religious phenomena was undoubtedly very imperfect. True, even here great advances bejond 
the age which preceded, are noticeable. People had ceased to regard the origin of the Jewish and Christian religion as a supernatural event and as the immediate work of God; all religions were placed upon the same footing, as species of the same kind; and efforts were made to discover their common characteristics and the law of their origin. But the people of that period were not yet able to arrive at the true essence of religious ideas and sentiments. They were hardly in a position to describe them properly, let alone to explain them. Of the hypotheses devised to throw some light into the darkness that hung over the beginnings of religions, not one proved itself competent to supply what was hoped for. All that they could derive from these fictions was that notable caricature of religion which their age had directly before its eyes, and to free themselves from which they strained every nerve. With the keen vision of hate they uncovered all the infirmities of religion, all the terrors and iniquities which have followed in its train, all the injurious effects to civilisation which have proceeded from it. They created a negative picture of religion, which has lost nothing of its partial historical truth by the fact that many of its features are farther withdrawn from our immediate experience than they were from that of the times in question.

But it was the nineteenth century that first worked out the true psychology of religious man, and again came into possession of that spirit of congeniality which is absolutely necessary to our entering into the mental life of far-distant times. To the men of the rationalistic age the history of religion was simply the history of the obscuration of the pure, natural religion, which was supposed to be constituted of a rational idea of God and a system of humane ethics, and which was indistinctly conceived at times as the logical, and at times as the historical, antecedent of the concrete religions. The latter appeared as the corruption of the natural and simple order of things-a corruption produced by superstition, by the wily exploitation of human credulity and human needs, by the scheming machinations of the founders of religions and of priests, by human delight in the marvellous, by the falsification of the natural moral sentiments, and by the stirring into life of fanatical passions. We know 
to-day that this so-called natural religion is nothing more than a product of late abstraction and reflection; that the motives and selfish interests above cited have been abundantly at work in religious history, but are nevertheless unable to explain the internal motive force and tremendous vitality of these spiritual products. We know to-day that religions spring with the same necessity and in conformity with similar laws from the depths of the human mind as language and art, and that they form an integral constituent part of the structure of civilisation and an important weapon of humanity in the struggle for existence. In symbolical form they embody the highest treasures and highest ideals of national existence; in its gods humanity beholds the imaginative perfection and explanation of its view of the world; and in its religious practices, in its worship, in prayer, it strives to realise the wishes and aspirations which seem to lie beyond the reach of its powers.

Many a riddle still remains to be solved, as is natural in a domain that extends into the most hidden recesses of the human soul, and whose obscurity is augmented by the fact that in the majority of cases the most important and significant elements must be collected with infinite pains from the rubbish of fantastic traditions. But upon the whole the active labors of a century which calls itself with pride "the historical century," have borne their fruits. With respect to the intrinsic character and the significance of religion for civilisation, there is now every reason why a unity of opinion should prevail among all who take their stand on the common ground of modern scientific research, whether they be friends or opponents of religion.

But how does a knowledge of what religion has been in the past affect our estimate of it in the present? Do we approve of an institution or phenomenon, because we understand how it was once possible, nay, must have existed, and what it signified? We understand to-day the Roman law, the Ptolemaic astronomy, the scholastic philosophy, feudalism, and absolute monarchy, thoroughly; we know the conditions which gave rise to them, the necessity of their appearance, and the measure of their performances; but does it occur to us, for these reasons, to perpetuate and make them im- 
mortal because they had once an historical significance? What an institution in its essence is, what in past times it has accomplished, is an inquiry that must be conducted with quite different means from that whether it is applicable to a definite present set of relations and necessities. The historian can render this task more easy by teaching us to understand the general laws and necessities of national life from the analogies of the past; but as a prophet he will always be one that looks backwards, and it is ever to be feared that he, too, will see the present in the light of the past. For to him alone does the past lift its obscuring veil, who, forgetful of self and unmindful of sacrifices, can listen to the voices of remote times and peoples, who with a mind of Protean cast has the power to trans. form his intellectual being into that to which, solely by description, he seeks to give new life and form. The past becomes a part of him ; he loves it, he admires it. And from the reanimation of the past in historical pictures to the attempt of a renewal of it in life is but a single step.

Innumerable are those who have succumbed to this temptation. The entire religious tendency of the nineteenth century exhibits this process on a grand scale. This tendency is based on profound antiquarian studies of the past-on that newly awakened historical interest, which aims not only to criticise but to understand religion and ecclesiastical institutions. Much that in the previous century seemed dead or destined to perish, had been restored to life by it. The whole historical structure of the Christian religion, which at the close of the age of rationalism only existed, it would seem, as an artificially preserved ruin, has received, through the instrumentality of these methods of thought, new supports, and has again been made habitable for the human mind. Unmindful of the complaints of churchmen, the future historian of civilisation will have to characterise the second half of the nineteenth century as a period of religious renaissance. And it is no accident, but a symptom of deep import, that this century has completed almost all the great cathedrals which were left unfinished and in partial ruins by the middle ages, and placed them in their colossal grandeur before the world as lasting monuments of its habits and tendencies of thought. 
Yet the spirit of science has also not been inactive. Political progress has freed it from the despotic police supervision which even in the eighteenth century heavily oppressed it. In principle at least, freedom of thought and inquiry are to-day acknowledged by all governments, with the single exception of the Roman curia, although in practice there are by no means few efforts made, by influencing its representatives, to have that proclaimed which it is desired should be proclaimed. Infinitely great has the number of workers grown, the instruments of inquiry, the confidence of the human mind in itself, and our power generally. And if formerly people could conceive of no other science than such as stood in the service of the church, to-day science claims it most emphatically and confidently as its privilege and duty to search and test the logical truth of the most sacred traditions, and thus to base the thought of future generations, not on the naïve faith of their fathers, but on the demonstrable truths of actual present knowledge.

I I.

Between the two groups of modern humanity, of which the one seeks to retain the Christian religion in its historical form as the precious heritage of the past, and the other to supplant it by a new Idealism formed in harmony with the spirit of science, a third class stands, which plays the part of a mediator. This class concedes that the traditional forms of religion are in great part unadapted to the modern mind, and that historical Christianity is in need of improvement, but contends that religion is an ineradicable constituent of all higher civilisation, and must remain so, and, particularly, that Christianity is the absolute religion, that is to say, that in Christianity as rightly understood and naturally developed all the necessary elements of the true religion of the future are contained.

I should like, in the following pages, to subject the contentions of this mediatory group to a critical examination, and to discuss the question whether it is at all possible for one who resolutely takes his stand on the ground of modern scientific thought, logically to have religion in the historical sense at all. 
In effecting a mediation between the religious and scientific views of the world,-views which appear to be separated from each other by a profound intellectual abyss, - two ways may, generally speaking, be pursued. Both have been frequently trodden since the days of rationalism. I shall discuss each separately.

The attempt may be made to resume, in a form more adapted to modern times, the work of the reformers of the sixteenth century; to go back even more thoroughly than they did to the original and simplest forms of Christianity, to remove in toto the superstructure which has been reared upon it in the course of time, and to exhibit to humanity " the pure doctrine of Christ" as the source from which to-day, as a thousand years ago, true comfort may proceed, as the simplest, purest, and most exalted expression of the divine and hu. man that has ever yet been discovered. Many of the most erudite workers in the field of critical theology which this century can show have placed themselves in the service of this idea, which is preached with particular enthusiasm by the so-called "free-religious" and Unitarian confessions, and which at times has also exhibited a noble and conciliatory activity in the homiletical work of some mild-minded and liberal clergymen in the evangelical churches. But our special inquiry here must be concerning the logical and scientific foundation of this modernised primitive Christianity, and on this point it must be frankly stated that the more faithfully such a Christianity reflects the biblical character, the remoter it is from our modern thought, and the more it is dominated by modern ways of thinking, the more unhistorical and hence the more unchristian it becomes.

The "pure doctrine of Christ," the genuine, primitive form of Christianity, is a Utopia of biblical criticism. What we actually possess, in the form of historical documents, is that conception of the doctrines and life of Christ which was put in writing several generations after his death, and which, from amid a much greater number of contemporaneous attempts, met by preference with the approbation of the church. It is a hopeless task to attempt from these late records, which betray the most various intellectual influences, to derive the authentic doctrines of the oldest form of Christianity. No method, subjective prepossession only, can here render 
a verdict. The things that appear especially consistent and homogeneous to individual theologians and critics are stamped as the genuine utterances of the Master. As every time has done, so ours also constructs its picture of Christ to conform with its wishes and wants.

But granting even that there is nothing objectionable in this, and that this procedure is perfectly justified, a number of difficulties still stand in the way of this movement which have stamped the procedure of even the most ingenious of its representatives as the outcome of pure subjective caprice. All the written sources which we possess of the life and teachings of Christ contain much that is in the highest degree repugnant to the modern mind. I refer particularly to the miracles. The difficulties which they present may be disposed of in various ways; as, to give an example, by the method of the early rationalistic thinkers, who accepted the miracles as facts, but sought to give them a rational explanation, or by that of Strauss, who held that they were the mythical and poetical raiment of religious ideas and sentiments. Yet no art of interpretation will banish from the world that fact which the poet expressed in the words:

\section{"Das Wunder ist des Glaubens liebstes Kind,"}

The fact that the entire cast of thought and sentiment of early Christianity is saturated with the belief in the marvellous, and with the expectations, nay, with the actual need of miracles, and that this is not an adscititious ornament which can be doffed at pleasure, like a dress which we have outgrown, but is of the very essence of Christianity. Here is rooted that childlike and simple belief in the limitless and God-coercing power of prayer, for which no natural laws nor force of necessity exists, which is omnipotent as the Godhead itself, and as all-powerful as desire. Here is rooted that ardent conviction of the near collapse of the entire world, of the coming king. dom of perfection which shall proceed, not from deeds and thought, but from faith and grace, and shall crown all human desires with glory. And intimately connected with all this stands the idea, visible in the background of all the moral prescripts of the gospels, and painted in the strongest colors, of a system of punishments and re- 
wards in the world beyond; which makes of a God of love, a pitiless, infuriate God of vengeance.

These things are so intimately interwoven with the modes of thought of the synoptic writers that it is impossible to separate them therefrom without doing violence to the internal connection of their doctrines. They who seek after a more spiritual conception may, it is true, find it in the gospel of John. But this book is so completely dominated by the metaphysical-religious speculation of the second century, and by the effort to bring the history of the life and doctrines of the Nazarene in the service of the Logos idea, that the modern mind can only with great difficulty find a common ground of understanding with it.

The task of the modern reformers is, for these reasons, a very difficult one. They cannot but concede that Christianity, even in its purely evangelical form, contains much that is foreign to us, and that the elements of which it is composed must in part be excised and in part improved by criticism and interpretation.

But the more the critical sense which is brought to bear upon this task is developed in the spirit of modern scientific thought, the more will historical Christianity shrink to the form of a mere colorless abstraction, and ultimately nothing remains of its exuberant yet visionary mental world but the picture of a philanthropic life joined to a strongly developed consciousness of God, which proclaims a popular morality in commandments and parables. But even this latter is inevitably exposed to the same fate as the other ideas. It is dominated throughout by the extremest notions of rewards and punishments, which the expectation of the doom of the world places in the very immediate future. It is impossible to take the system as a whole, and it must be made the subject of violent interpretation to acquire any fitness for the needs of modern life. Its principles are systematically turned and twisted till they have acquired in some direction practical utility. And who at this day can forget, that this system of morality, wherever and whenever attempts have been made literally and faithfully to imitate it in practical life, has led only to wretched caricatures? Moreover, it is again and again freely remodelled in the spirit of modern ethics, its offensive elements char- 
itably cloaked, its useful ones developed to the utmost, and finally here too a complete set of wholly modern ideas consecrated by the borrowed authority of a venerable antiquity.

And therefore I repeat my contention, that the modern reformation, this modern, pure, and scriptural Christianity, will, the honester it is, all the more surely lead its adherents away from Scripture and from Christianity and ultimately bring them to the adoption of a popularly expounded, but philosophically established, ethical system.

I shall now take up the second of the two methods above mentioned. That which we have just considered was known and affected even by the eighteenth century. The discovery of the second is a merit of the present time. The honor belongs in a pre-eminent degree to the speculative philosophy of Germany, and to the intimate relations with theology which this philosophy, especially in the school of Hegel and Schleiermacher, entered into in the first half of the century. (Kant's philosophy was not put to similar use until later.) All these movements, whose rich literary ramifications and development may be followed to the present day in Otto Pfleiderer's excellent and erudite work, "The History of Protestant Theology in Germany Since Kant," * have also begun in recent times, through Green, Caird, A. Seth, J. Martineau, R. Flint, and F. Robertson, to exert an influence on Anglo-American intellectual life.

The common fundamental feature of this second movement is, that it proposes to accept as pure Christianity, not only the most ancient forms of Christian doctrine accessible to us, but also the entire system of dogmatic thoughts which in the course of the centuries primitive Christianity has produced. Christianity, these men say, has historically existed and acted in these maturer notions. It is not permissible arbitrarily to separate them from it, and to reverse by any authoritative edicts the real historical development. On the contrary, we now may and must continue the process which, by the tenor of dogmatic history, is the process which has continued for centuries, and give to the dogmas the form which best accords with

* Translation published by Swan, Sonnenschein \& Co., Londor, I8gr. 
modern spiritual needs. To-day as in the days of incipient Christianity, we see by the side of the naive literal belief, which takes no offence at incomprehensible things if they only suit the needs of its heart, a gnosis arise which strives to reconcile faith and knowledge, religion and intellectual culture; a gnosis which to the unbelieving sceptic quotes the words of the poet:

\section{"Die Geisteravelt ist nicht verschlossen; \\ Dein Sinn ist at ; dein Herz ist todt! \\ Auf! bade, Schiiler, unverdrossen \\ Die ird'sche Brust im Morgenroth!",}

It is perhaps even more difficult to give a succinct and comprehensive notion of the ideas of this speculative theology, than of the results of the New Testament exegesis of which we spoke above. All gradations are here represented, from tender, conservative regard for the traditional beliefs of the sects and the needs of the pious heart to the boldest speculative interpretations and critical restrictions of dogma, which utterly discard the historical form and hold fast only to a central germinal truth. The present inquiry will restrict itself to those representatives of this gnosis, who as a matter of principle grant the greatest field of action to the rational development of dogma, and represent its philosophical elaboration in its finest and most complicated form. I shall attempt to signalise the ideas which may to-day be designated as the most spiritualised expression of the Christian view of the world.

And first let us hear a greater mind speak. In Ludwig Feuerbach's essays on the nature of religion and Christianity the following sentences occur:

"The Christian religion is the revealed inwardncss, the objec"tively expressed self of man; the contents of his highest aspira"tions; the essence of man purified and freed from the limitations " of individuality; yet all subjectivised, that is intuited, known, and " worshipped as a separate, independent entity, wholly distinct from " himself. Religion is essentially dramatical. God himself is a "dramatical creation, that is to say, a personal being opposed to "man. He who takes from religion this idea, takes from it the gist "of its being, and holds but the caput mortum in his hands." 
These sentences of Feuerbach express with the greatest generality and precision the innermost nature of the Christian view of the world. They characterise excellently the point that cannot be given up without destroying the religous view as such. What I refer to is dualism; the dualism of the divine and the human, of the world beyond, and the world that is, of holiness and sin; dualism conceived not merely as a mode of view and of conceptual distinction, as a working contrariety in things that by their nature are one, but as a metaphysical difference, an actual contraposition of two worlds, of two kingdoms of existence, which are totally separate, no matter how extensive the relations of the one to the other may be. Only on such a supposition is that possible which Feuerbach, with inimitable aptness, called "the dramatic element" of religion. The history of humanity, the history of its religious life particularly, is no monologue of humanity with itself into which life and advancement enter solely through the multitude of the ideas created by individuals within the race itself. It is an action or process in a higher sense, an interactivity between two worlds, in which, it is true, humanity, to a certain extent, shapes its own fortunes and destiny, but at the same time is also constantly exposed to the interferences of a power which stands beyond and above it and to which it has to accommodate itself. And whatever artifices and care many of the representatives of the modern gnosis may employ to conceal this fundamental assumption, and to substitute for it the point of view of the immanence of this power in the world, still any radical breach with it is impossible without endangering the very foundations of the religious sense of humanity itself.

The indispensability of this dualistic opposition and separation is equally well exhibited whether we take as our starting-point the existence of the world at large or the individual consciousness of man. The religious mode of view knows of no other way of asserting the rights and activity of the mind in the All than by making all existence assume a personal life in an infinite, self-conscious, and ethically perfect being. The emotions and experiences of one's heart, its vacillations between humility and exaltation, remorse at the consciousness of one's own imperfections, the inspired flight of 
the soul to higher realms of existence, appear as the intercourse of man with some extraneous power, allied to man and yet above him, in which the sum of all excellence to which thought and experience have ever led man, has its eternal source.

These ideas constitute the point of view which is decisive of the history of humanity, particularly in what concerns religion. The history of religion is, in accordance with these ideas, conceived as a continuous self-revelation of God in the world of man. True, this view seems to be contradicted by the fact that the self-revelation of this infinitely good power is effected in the case of by far the greater part of mankind in a very insufficient manner-in the form, namely; of crude and superstitious notions which stand in need of constant purification by reason. But the explanation of this fact is sought in the idea of a divine pedagogical training of the human race, and in the theory that religion is not an immediate self-revelation of the absolute, but passes through the medium of the human mind and consequently must be conditioned by its character.

Christianity, now, especially appears as the highest form of this self-revelation of God in humanity, that is to say as the absolute religion, which, in its historical forms, it is true, is as little free from adscititious ornaments and transient obscurations as other religions, yet in its essence can be as little improved as it can be discarded. This innermost essence of Christianity the majority of the representatives of this modern gnosis declare to be the conviction that all men are from the beginning children of God. In this idea two things are contained : submission to the will of God who is conceived as a kind parent and who in pity and love does everything for the best; and the imitation in our own thought and conduct of the ethical perfection conceived incarnate in God. The entering of man into this relation is designated the kingdom of God-a notion which constitutes the ideal goal of history. The condition of mind on which the kingdom of God rests is prefigured in a typical manner in the founder of the Christian religion. His person and his life are a guarantee of the possibility of this ideal, and exhibit at the same time the means of its accomplishment: namely, the helping love of God, which has infused into this one individual the whole plenitude 
of its being, so far as this is at all possible with human capacities, that humanity may have in it a direct living picture of the highest fulfilment of its religious and moral destiny. The historical Christ is the ideal of humanity, supported and ensonled by the spirit of God.

The modern gnosis here goes back to the Paulinian interpretation of the Christ-idea. The consideration of the speculative diffculties of the idea of the Trinity is thus rendered superfluous for it. This notion is treated by the majority of its representatives simply. as a dogmatic antiquity; its place is taken by the modern ideas of a distinction between the person of Jesus and the principle or spirit of Christianity, which is synonymous with the contrast of the idea and its revelation, the eternal and the temporal, of the inward essence and its historical realisation. That it employs the notions of idea, principle, and essence wholly in a Platonic sense, as the highest metaphysical realities, is self-evident.

More distant still is the attitude which this speculative theology assumes towards another idea which proceeded from the Rabbinical school of thought of Paul : the notion of salvation or redemption in its connection with the expiatory death of Christ. From these conceptions of punitive suffering, of a vicarious atonement of God in his own person-conceptions of such juristical refinement as to be wholly unacceptable to modern modes of thought-the modern gnosis has upon the whole resolutely turned away and taken refuge in that more spiritual and more profound idea which in early Christian times the author of the gospel of St. John promulgated. The death of Christ is redemptive only in the sense in which Christ's total history is redemptive, as the direct and prefigurative incarnation of the true religious relation between God and man. This is, it is true, applicable in a quite special sense to the Death; for it was by this that the eternal truth was manifested, that not only does all salvation accrue to man from the sacrifice of his own self in duteous and patient love, but that all the life of God is an emanation of this self-surrendering excellence, of this bliss of self-sacrifice. Still, there is one thing that is common to all the representatives of this movement as distinguished from the former, and that is this: 
they do not content themselves with picturing the activity of Jesus Christ in general outlines solely as one which is blessed and significant by example and doctrine for humanity, but they assume a continuous and active presence of the Christian principle in humanity, by means of which the moral discord in individuals is overcome, and in the personal spiritual life of individuals divine and human nature are united. This is the most speculative interpretation we have of the old dogmatic notion of redemption, which from its original character as a single isolated phenomenon of history has here become the constant activity of a Christian principle, and an ever-living precedent of Christian life.

It would be a prolix and wearisome task to go through in this way the whole dogmatism of this speculative theology. The fundamental ideas which we have discussed will suffice to show the manner in which, on the one hand, it spiritualised the allegorical notions of popular Christianity, but on the other left untouched the gist of the religious view and the dramatical or dualistic opposition of the divine and human. The notions of grace and sanctification, the notion of the church as a living, organised instrument of salvation, spring directly and logically from these fundamental ideas.

In the province of ethics this movement has a much easier task than the churches based on the New Testament. 'As it seeks to establish, not a primitive Christianity, but a modernised Christianity developed in the spirit of recent times, there is no necessity of its being incommoded by the ethical crudenesses of early Christianity, but it is in the same position to work these crude nessesover critically as it did the asperities of the old dogmas. It can assimilate most of what it needs from modern philosophical ethics, and content itself with giving to what it has thus borrowed a metaphysically religious background derived from dogmatic traditions.

That this modern gnosis is in a constant state of vacillation with respect to the practical things of life, is a necessary consequence of its fundamental assumptions and of its position towards the doctrines of the church. Its foremost representatives acknowledge without any reserve that the true source from which religious emotions and sentiments flow is the symbolic or imaginative faculty of 
man. The grandly simple pictures in which the ancient Christian faith found satisfaction are now in the course of time inevitably disintegrated by the critical reason. The speculative theology itself proclaims that its vocation is one of coopperation towards this end. But it maintains nevertheless that the fruits of this work, the speculative interpretation of the dogmas, their exaltation into the sphere of the Idea, are fit only for initiated minds, and are caviare for the general. The general, the people, want and will use religion in the form which its fancy has created, and it cannot be revealed to it in any other. Progressive in its theories, this gnosis is in its ecclesiastical practice thoroughly conservative. It thinks two kinds of thought, and speaks two kinds of languages, according as it finds itself in the pulpit or in the professorial chair. And it is in just this procedure that it assumes a position which it is very difficult to attack. He, who working for a sound and progressive popular enlightenment on the ground of a unitary view of the world, opposes the further use of the antiquated and effete allegories of the old religions, is told that he is behind the times, and that religion, nurtured by the spirit of modern science, has become something different from what it formerly was. In very strict ecclesiastical quarters this gnosis is looked at askance, and accused of insincerity, nay, of secret alliance with unbelief; but the movement never allowed itself to be led astray by these accusations, and has never failed to assert its right of coöperation in the common work of the Christian church. For though it pretends to be in the hands of the thinking theologian a means of bringing into harmony the faith which he must confess and the thought which he cannot abandon, it yet admits, that with the majority of mankind the allegory will always remain an essential element of religion, and that therefore the task of scientific theology can never be to destroy these vessels of religion, but only to exercise a watchful care, that with the form the spirit also may not be lost.

III.

The question now arises, - and this brings us back to the considerations of the first part of this essay, -Does this rationalised 
Christianity of to-day really meet the demands of science, and if it does not, is it in the power of the modern scientific world-conception to furnish from its own resources some substitute for the religious views of the past?

My answer to this question will be short and concise; for the existence of The Monist, the fundamental idea of its management, and the total character of the efforts which it has hitherto made, speak with sufficient emphasis. And we may, therefore, with the greatest respect for the scientific zeal and the personal ability of many of the representatives of this mediatory theology, say, without further ado: This rationalised Christianity of yours also is myth and symbol; it still adheres to that "dramatic" division of the world which our imaginations produced, and to the metaphysical dualism of God and man; it cannot lift itself to a rigorous conception of the All in One, for which God is in the same sense a simple function of human thought as thought is a function of the human organism. The God on whom all depends in religion, the God whose name is "Father," the God of love and goodness, the God from whom all great thoughts and all grand resolves spring, the God who sanctifies us and lifts us above the earth-to displace this God from the world in which he has no place, into the inward being of humanity seems at this day so strange, nay, inconceivable, only because we have accustomed ourselves (and down to the times of Mill and Feuerbach, even strict monistic thinkers like Spinoza fell victims to this illusion) to mingle together in the idea of God two wholly distinct ideas-the ideas, namely, of nature and of an ethical ideal. To preserve this latter inviolate, and to secure it from all encroachments of human caprice, one thing alone seemed to the naive dramatic modes of thought of early times a competent safeguard : the ideal must in some locality be real; the highest to which human thought and aspiration can exalt itself must be sought and must exist in some superhuman reality. And what reality could be better adapted to this than one- on which even nature was conceived to be dependent? The entire history of the development of the idea of God in the Græco-Roman and Hebrew worlds, the confluence of these two streams of thought in Christian speculation, exhibit in the clearest 
possible manner these motives, which here I can only lightly touch upon.

But this combination of the law of nature and the law of ethics in the idea of God, although solving some of the difficulties of humanity, has plunged it into incomparably greater ones. Through all the centuries of Christian thought a succession of desperate attempts may be traced to establish a theodicy, that is to say, attempts to demonstrate the existence in nature and in history of a God which. harmonises with the ethical ideal. Even Kant could undertake to demonstrate the "necessary failure of all attempts at a theodicy," and whoever might still have entertained any doubt as to the correctness of this demonstration, such a one must surely have been convinced of it by the scientific development of the past century. That which was indissolubly welded together in the Christian idea of God is to-day disintegrated into its component elements. The Lord above nature, the Spirit behind nature, have been rendered inconceivable by the modern notions of the conformity to law of all natural occurrences and of the unity of all existence. The spirit immanent in the All no thinker will deny, for this spirit manifests itself in an indisputable manner in the fact that this All is a cosmos, not a chaos, that not only the caprice of chance but also the laws of necessity rule in it, and that the personal self-conscious mind springs from its midst. But from this recognition of mind in the All, there is no bridge that leads to the old idea of God. We cannot worship the All as a moral ideal. We involve ourselves in absurd complications when we attempt to derive the actions of natural events and their conformity to law from ethical categories, and it is no less a desperate undertaking to imagine that we can draw impulses for our moral thought and conduct from nature. The adaptation of means to ends, the teleology, that rules in the All, is veiled for us in the deepest obscurity. All that we can unravel of it has no resemblance to that which, according to our notions, is ethical :

"Denn unfiilhlend ist die Natur,"

she does not know what love or mercy is ; she knows only the omnipotent power of universal laws; she knows only the rights of the 
whole, to which she sacrifices with unconcern the individual; she rcvels in the double pleasure of unceasing creation and unceasing destruction; she arms unpityingly the strong against the weak; in crises of annihilation she restores the disturbed equilibrium of things; but the palm of peace no one has ever seen in her hand. And we? We stand amazed at her might and greatness, at the plentitude of her powers of creation, at her myriad play of forces, at the inexhaustible wealth of the relations with which she binds being to being, creates and mediates contrarieties, and amidst the most varied change and alternation, ever remains one and the same! But our prototype, our God, she can never be. To him we must look up; but on nature, despite her might, despite her stupendous grandeur, we look down. She did not whisper in our ears that in us which is best and highest. That did not come to us from heaven; we ourselves won it by hard struggles, by terribly severe, self-imposed discipline. It is not of nature; it is above nature. Through us something has come into the world that before us did not exist-something that the most exuberant creative magic, or nature's grandest mechanical dreams, could never replace. The day on which first a human being pressed his weaker fellow-man to his breast and said, "Brother, not mine, but thy will be done ; I will give up my desires that thou also mayst be glad"; the day on which man first lifted up his head and said, "Let us make the world good in the likeness of the picture that has become living in us, just as it should be"; this is the great and sanctified day in the history of our race on earth, the Christmas day on which God was born. But not as the religious fancy has expressed it, the day on which God became man, but the day on which man began to become God, that is the day on which he began to feel spiritual powers in his breast that transcended his animal impulses-powers to which the majority of humanity was still as remote as heaven from earth.

This strict anthropological conception of God as the ideal which is always newly creating itself in the struggles of humanity, which is no Being but a Becoming, solves the innumerable difficulties which the idea of God has hitherto placed in the way of rigorous scientific knowledge and the construction of a unitary conception of 
the world. This God has nothing to do with the All. We need not seek him in the All or behind the All, and need not fear that any progress of our knowledge will make his existence a matter of doubt with us. Concerning the real validity of this idea we need not bother ourselves with more or less weak and insufficient demonstrations: the whole history of humanity is evidence of it if we but know how to rightly interpret it, and the stumbling block of the old theological idea of God has become the corner-stone upon which the new scientific conception is built.

Nature and human history the work of an omnipotent and allkind being that is mediately and immediately active in all events, nay, sacrificed himself in his own person that he might realise in this world his purposes! Compare the principle, the active force of this world-drama, pictured by the religious fancy as the highest power, the highest wisdom, and all-merciful love, with the real spectacle of the world! Is there anywhere a more pronounced contradiction, an obscurer riddle, a more inconceivable contrast between purpose and accomplishment? This world of cruelty and woe, in which one creature feeds on the heart-blood of another, in which here and there from seas of mud and dirt a form of light springs up, in which every nobler production must be bought with torrents of blood and tears; this revelation and self-manifestation of God in humanity, which everywhere appears joined to definite historical suppositions, which lacks all the conditions of true universality and of indisputable evidence, so that instead of forming a means of union it has become the source of dreadful contentions; this work of salvation and sanctification which is so restricted in its effects that "the kingdom of God" is still a dreamy vision of humanity, so restricted that we still see the majority of men, despite the most extraordinary supernatural dispositions, still remain far behind the simple ideals of natural ethical commandments, that hate and dissension, cruelty and selfishness, perform their unhallowed work-is this the work of infinite power and infinite wisdom? What claims theodicy makes on human thought! And how different the picture is, the moment we abandon the false theocentric point of view and assume the anthropocentric! Instead of a belief which all facts contradict-an 
idea which elucidates them all. No one can say how we are to interpret facts as the work of a holy and absolutely perfect being; but it can be shown, step by step, how in this, our human world, more perfect things spring from imperfect things, moral and mental laws from the blind play of natural forces and powers, the conscious energy of will from blind and unreasonable impulse, law and love of man from the selfishness and warring of all against all, and the notion of the unity of the race from infinite disruption and disunion. We must not allow ourselves to be led astray or discouraged here by the changing undulations and tremendous crises of this battle for the good. The ideal springs out of a dark abyss. The roots of our being are deep laid in nature, yet we struggle to exalt ourselves above it. No wonder, therefore, that time and again it draws us back.

The greatest and sublimest spectacle! A tragical one, one filled with struggle and suffering, and yet one infinitely full of hope. For it shows us the inexhaustible grandeur of the human mind; it shows us the good, the ideal, as a tremendous real power, a power eternally becoming, surely forming itself out of an infinitude of individual deeds, a power fully incarnate in no one person, yet active and living in humanity. Not a tangible activity, and yet one of the realest of facts. A supersensuous, nay, if you will, a supernatural realm of thought; not the faded reflection or shadow of a grandeur and power beyond us, but the fruit of the noblest activities and powers of this given, existing world, antagonised in life, but grand and powerful in thought; imperfect even in its boldest flights, but bearing within it the germ of greater things to come.

Here is the true point of union for Christian dogma and science. Here is the God in which science also may, nay, must, believe. Not humanity in its empirical reality, but the ideal world developed within the human realm of things-the spirit of humanity. This is the only true object of worship. Before it we are humiliated, and by it we feel ourselves exalted. From it we receive all the good that life bestows upon us; it gives us light and peace and lucid thought. And what higher, nobler thing can a life produce than the feeling that it has not been unworthy of this great ancestry, that it has 
helped to keep alive this holy fire, that it has helped, perhaps, to fan by its own life this living flame to greater heights?

Here is the true source of the ideas of accountability and of salvation. We are not responsible to a being outside and above us, but to our own selves and to humanity, from which we have received the best that it had to give, and for which we must return what we ourselves have produced. This consciousness of being thrown utterly on the resources of one's own self, on one's own powers, was first created in the human mind by science and the technical arts, (as that most venerable and most sacred of all myths, the legend of Prometheus, so profoundly indicates,) and this consciousness will, by the progress of knowledge and power, be made more and more the dominating one of humanity. This is not a consciousness of omnipotence; it does not exclude the subjection of man to the inexorable laws of the universe; but it demands the enlistment of all the powers of the race: for nature does not give us more than we wrest from her by arduous toil.

And as humanity is accountable only to itself, so do the means of its salvation lie only in itself. Not in any one individual, but in the spirit in it which ever works onward and upward. Yet this spirit is not an unpersonal existence; it must be possessed again and ever again by living men. And no one can serve humanity or augment its spiritual treasures or reincarnate in himself its holiest possessions without first having and feeling within himself the blessing of what he has done. And thus the profoundest significance of human life on earth may be formulated and embraced in that saying of the poet which was throughout conceived in the spirit of our times, and would have been wholly incomprehensible to the mind of those who gave us our faith-in the words:

"Erlösung dem Erlöser."

F. JODL. 